zeszyt $152,2018,11-31$

doi: $10.4467 / 20833113$ PG.17.028.8251

Instytut Geografii i Gospodarki Przestrzennej UJ

Wydawnictwo Uniwersytetu Jagiellońskiego

\title{
OBIEKTY ZABYTKOWE W PRZESTRZENI WIRTUALNEJ GRY INGRESS - STUDIUM MAŁYCH MIAST KRAKOWSKIEGO OBSZARU METROPOLITALNEGO
}

\author{
Matgorzata Bajgier-Kowalska, Mariola Tracz, Radostaw Uliswak
}

\section{Historical sites in the virtual world of the Ingress game - case study of small towns in the Krakow Metropolitan Area}

\begin{abstract}
Ongoing changes in communications technology create new opportunities not only in terms of acquisition of data on urban cultural heritage, but also in terms of active participation in the creation of such heritage. One example of this is interactive games, which are used in the field of tourism, including urban games and rural games. One of such games is Ingress, which is played in real time in virtual reality on mobile devices. The game board for Ingress is a real map of the world, produced by Google Maps, with superimposed virtual objects (portals) that reflect physical sites in geographic space submitted by gamers and approved by the entity managing the game.

The aim of this study was to identify sites in urban space that are submitted to the world of virtual reality in the Ingress game. In addition, the goal was to determine how these sites affect the tourist offering of the city. The study consisted of an analysis of the number and type of historical sites officially listed in the register of stationary historical sites in 12 small towns in the Krakow Metropolitan Area. The list was then compared with their presence in the game of Ingress. The study analyzes the nature of the virtual game map for towns, presents an inventory and classification of sites submitted by gamers, and estimates the rank of historical sites among all sites available in the game. Research has shown a strong dependence of the number of portals introduced into the game of Ingress on the number of residents of local municipalities. The virtual world of attractive sites introduced by gamers into Ingress
\end{abstract}


is substantially different from that shaped by tourist guides and the actual history of cities. The number of Ingress portals per city does not reflect the nature and number of historical sites registered as cultural heritage sites. In small cities, the nature of the portals is similar. Most portals are dominated by commemorative plaques, sculptures, and monuments as well as religion-oriented sites including churches and chapels. On the other hand, the number of recreational, educational, and cultural sites is negligible. The employment of new local marketing strategies based on social networks and urban games is not very common.

Keywords: Ingress game, Krakow Metropolitan Area, small towns, monuments, virtual space, tourism

Zarys treści: Zachodzące zmiany w zakresie technologii komunikacji otwierają nowe możliwości w zakresie nie tylko pozyskiwania informacji o walorach dziedzictwa kulturowego miasta, ale także czynnego uczestnictwa w ich tworzeniu i kreowaniu. Przykładem są różnorodne gry interaktywne wykorzystywane w turystyce, w tym gry miejskie i terenowe. Jedną z nich jest gra Ingress, prowadzona w czasie rzeczywistym na urządzeniach mobilnych w rzeczywistości rozszerzonej. Jej planszę stanowi realna mapa świata (Google Maps) z nałożonymi obiektami wirtualnymi (portalami), odzwierciedlającymi rzeczywiste obiekty w terenie zgłoszone przez graczy i zaakceptowane przez podmiot koordynujący grę.

Celem badań było dokonanie identyfikacji obiektów z przestrzeni miejskiej wprowadzanych do rzeczywistości wirtualnej gry Ingress oraz ustalenie jej potencjalnego wpływu na kreowanie produktu turystycznego miasta. Autorzy przeanalizowali pod względem liczby i rodzaju obiekty zabytkowe wpisane do rejestru zabytków nieruchomych w 12 małych miastach Krakowskiego Obszaru Metropolitalnego, a następnie skonfrontowali ich istnienie w przestrzeni wirtualnej gry Ingress. Analizowano charakter wirtualnej mapy gry w obrębie miast, dokonano inwentaryzacji i klasyfikacji obiektów zgłoszonych przez graczy i oszacowano pozycję obiektów zabytkowych wśród nich. Stwierdzono silną zależność liczby portali wprowadzonych do gry Ingress od liczby mieszkańców miejscowości. Wirtualny świat atrakcyjnych obiektów wprowadzonych przez graczy do gry znacznie odbiega od obrazu kształtowanego przez przewodniki turystyczne i historyczną przeszłość miast. Liczba portali w grze Ingress dla danego miasta nie odzwierciedla liczby i charakteru zabytków znajdujących się w rejestrze dziedzictwa kulturowego. W małych miastach charakter portali jest podobny. Dominują tablice pamiątkowe, rzeźby i pomniki oraz obiekty związane z kultem religijnym (kościoły, kapliczki itp.), znikoma jest natomiast liczba obiektów rekreacyjnych i edukacyjno-kulturalnych. Wykorzystanie przez władze miast nowoczesnej strategii marketingu terytorialnego, opartego na portalach społecznościowych i grach miejskich, jest mało popularne.

Stowa kluczowe: gra Ingress, Krakowski Obszar Metropolitalny, małe miasta, obiekty zabytkowe, przestrzeń wirtualna, turystyka

\section{Wprowadzenie}

Współcześnie turystyka miejska jest jedną z istotnych kategorii ruchu turystycznego. Jej celem jest m.in. odwiedzanie i poznanie miasta traktowanego jako dziedzictwo materialne i duchowe przekazywane z pokolenia na pokolenie, uznawanego za nie- 
podzielny element przestrzeni turystycznej (Kowalczyk 2003). Migracje turystyczne do miast obejmują zarówno wielkie centra historyczne i metropolie, jak i małe miasta, które dysponują zasobami dziedzictwa kulturowego oraz oferują turystom różne atrakcje i formy spędzania wolnego czasu (Mika 2007). W szerokim spektrum motywów podróży turystycznych do miast chęć obcowania z kulturą ma najważniejsze znaczenie, dlatego z turystyką miejską bezpośrednio wiąże się turystyka kulturowa. W literaturze funkcjonuje wiele definicji turystyki kulturowej. Według powszechnie znanej definicji zorientowanej na materialne obiekty dziedzictwa kulturowego turystyka kulturowa „(...) to podróże, których głównym celem jest zetknięcie się uczestników z zabytkami, zespołami i miejscami uznanymi oficjalnie i powszechnie za dziedzictwo kulturowe świata, kraju lub regionu" (Mikos von Rohrscheidt 2008: 53). Z kolei Metelka (1990: 41) mianem turystyki kulturowej określa zainteresowania podróżujących koncentrujące się na bogatej przeszłości ludzi bądź obszarów, zachowanej i odzwierciedlonej w zabytkach, historycznych okolicach, tradycyjnej architekturze i rękodziełach. Według Kowalczyka (2008: 13) jest to „zespół zachowań turystów związanych z ich autentycznym zainteresowaniem dziedzictwem kulturowym (zabytkami, folklorem, miejscami związanymi z ważnymi wydarzeniami itp.) oraz ich uczestnictwem w szeroko rozumianym współczesnym życiu kulturalnym”. Turystyka kulturowa posiada szerokie spektrum zainteresowań - od wydarzeń kultury wysokiej przez podróże tematyczne, językowe po relikty dawnej kultury ludowej (Mikos von Rohrscheidt 2008).

Coraz powszechniejsza dostępność do technicznych komunikatorów wyzwala nowe potrzeby i sposoby nieformalnej komunikacji między osobami i grupami zainteresowanych w przestrzeni elektronicznej, dotyczącej pozyskiwania i kreowania informacji o walorach turystycznych miast. Przykładem są różnorodne gry interaktywne, w tym gry terenowe.

Ingress jest grą terenową, opracowaną na urządzenia mobilne (tablety, smartfony) posiadające stałe połączenie z internetem i możliwość geolokalizacji za pomocą globalnego systemu pozycjonowania (GPS). Aplikacja została udostępniona w 2012 r., a firmuje ją Niantic Labs, będąca własnością firmy Google. Gra oparta jest na rywalizacji dwóch grup graczy (Ingress-Pomoc, https://support.ingress.com/hc/pl). Jedną stanowią Oświeceni (ang. Enlightened), oznaczeni kolorem zielonym, a druga to Ruch Oporu (ang. Resistance) oznaczony na niebiesko. Zadaniem obu grup jest przejmowanie portali (obiektów), budowanie między nimi połączeń, które tworzą pola dające przewagę nad przeciwnikami. W trakcie gry wykorzystuje się rzeczywiste podkłady kartograficzne pochodzące z Google Maps. Gra ta wymaga obecności i aktywności gracza w terenie - w miejscach, gdzie zlokalizowane są portale. Przyczynia się więc do wzrostu aktywności o charakterze turystycznym w przestrzeni realnej. Gracze poruszają się w terenie, a ich pozycja aktualizowana jest na bieżąco na mapie wyświetlanej w urządzeniu mobilnym. Mapa jest więc jednocześnie planszą gry. 
Na podkładach kartograficznych umieszczone są wirtualne obiekty (istniejące tylko w grze), tzw. portale. Ich lokalizacja oraz charakter nawiązują do realnie istniejących obiektów w terenie. Propozycje obiektów, które staną się portalami w grze, zgłaszane są przez graczy. W założeniach twórców gry portale powinny odwzorowywać obiekty rzeczywiste, ważne ze względów społecznych i kulturowych. Wyodrębniono pięć grup realnych obiektów: miejsca, które mają ciekawą historię albo wartość historyczną lub edukacyjną; ciekawe dzieła sztuki lub unikatowa architektura; ukryte perły lub lokalne atrakcje; biblioteki publiczne oraz miejsca kultu. Gracze, wybierając obiekty, powinni więc uwzględniać szeroko pojętą ich atrakcyjność dla potencjalnych graczy.

U podstaw podjęcia tematu pracy leży przekonanie, że rozwój technologii informacyjnych istotnie zmienia podejście potencjalnych turystów do percepcji przestrzeni miejskiej i komunikowania jej walorów. Zagadnienia te wydają się szczególnie ważne w przypadku młodego pokolenia, które swobodnie korzysta z nowych technologii, a wchodząc w dorosłe życie, będzie w znacznym stopniu wpływać na strukturę i funkcjonowanie miejscowości (np. poprzez kreowanie rozwoju turystyki w regionie). $Z$ tego powodu zainteresowano się przykładem gry wirtualnej Ingress, która z jednej strony wymaga od grającego aktywności - wyjścia w teren, a z drugiej - przez swoją regułę - obrazuje subiektywny odbiór przestrzeni miejskiej, w tym jego elementy funkcjonalne, kulturowe i edukacyjne. Jest ona najpopularniejszą na świecie grą opartą na geolokalizacji. Jej wersja wykorzystująca system operacyjny Android została pobrana ponad $10 \mathrm{mln}$ razy (https://play.google.com/store/apps/details? id=com. nianticproject.ingress - 10.11.2017). Badanie portali umieszczonych w grze Ingress stanowi zatem cenne źródło informacji o tym, jak gracze postrzegają atrakcyjność swojego otoczenia, a jednocześnie, w jaki sposób gra może wpływać na kreowanie odbioru wartości przestrzeni miasta na potrzeby turystyczne.

Wcześniejsze studium autorów nad obiektami zabytkowymi Krzeszowic i ich egzemplifikacji w wirtualnej przestrzeni oraz ich wykorzystaniem w turystyce (Bajgier-Kowalska i in. 2017) dostarczyło interesujących danych o wirtualnej przestrzeni turystycznej. W tym celu rozszerzono badania na kolejne małe miasta Krakowskiego Obszaru Metropolitalnego (KOM), aby ustalić odbiór przestrzeni miejskiej przez uczestników gry Ingress, w tym obecności obiektów zabytkowych, oraz ich potencjalny wpływ na rozwój turystyki w małych miastach.

\section{Badania nad percepcją przestrzeni miejskiej w geografii}

Badania wyobrażeń przestrzeni stanowią przedmiot zainteresowań różnych dyscyplin naukowych. Szczególnie wykazują je psychologia, socjologia i geografia. Do literatury wprowadzono termin „mapa wyobrażeniowa”, obrazujący subiektywną wiedzę o poznawanej przestrzeni przez człowieka (Trowbridge 1913; Wright 1947; 
Lynch 1960; Gold 1980) W badaniach nad percepcją przestrzeni ujawniają się dwa podejścia reprezentowane w naukach społecznych: behawioralne, związane z nurtem filozofii pozytywizmu, oraz nurt humanistyczny, wynikający z przyjęcia założeń fenomenologii. W ujęciu humanistycznym w odbiorze przestrzeni bardziej zwraca się uwagę na związek człowieka z miejscem, jego odbiorem i nadaniem mu znaczeń (Relph 1970; Yi-Fu Tuan 1987)· W badaniach geograficznych percepcję traktuje się jako proces społeczny, pośredniczący między człowiekiem a środowiskiem. Jest to pojęcie dynamiczne, oznaczające całość ludzkiego doświadczania świata, obejmującą wiedzę, teorię, mity oraz związki między zjawiskami (Guelke 1976).

W geograficznych badaniach percepcji środowiskowej eksponowane są relacje przestrzenne, a sposobem ich prezentacji jest mapa (Lynch 1960; Lisowski 2003). Jest ona przydatna, gdyż daje możliwość wizualizacji informacji obok stosowanego sposobu werbalnego. Wizualizacja wyobrażeń przestrzeni zawiera wiedzę o środowisku, jego wartościowaniu i preferencje indywidualnych osób. Mieszkańcy kierują się różnymi motywacjami w odbiorze i ocenie przestrzeni miejskiej. Wiedza ta może być istotnym punktem wyjścia nie tylko dla samorządów miejskich, ale także dla instytucji turystycznych. Według badaczy zajmujących się zagadnieniami waloryzacji, preferencji i postaw wobec środowiska badania dotyczące percepcji przestrzeni mogą mieć znaczenie praktyczne przy planowaniu (Saarinen 1973; Tobiasz-Lis 2013), a także jako jeden z elementów uspołecznienia procesu planowania (Libura 1990).

Geografia percepcji wykorzystuje przede wszystkim podejście behawioralne w ten sposób zbliżona jest przedmiotem i metodami badań do psychologii środowiskowej. Geografia potrzeb społecznych coraz częściej kładzie nacisk na indywidualne doświadczenia społeczne. Główną ideą ujęć humanistycznych jest traktowanie człowieka jako podmiotu badań, a sposobu doświadczania przez niego przestrzeni jako ich przedmiotu i treści. Przyjmuje się, że jednostki ludzkie posiadają zdolność autodefiniowania oraz „,definicji” warunków, w jakich się znajdują. Świat, w którym egzystują, jest przez nie w określony sposób percypowany, odczuwany, przeżywany i rozumiany. Pewne jego aspekty traktowane są jako ważne i nadawane im są wówczas znaczenia oraz wartości (Sagan 2000).

Jednym z kluczowych pojęć jest tu percepcja (z psychologii) rozumiana jako postrzeganie, spostrzeganie, uświadomienie sobie spostrzeganego przedmiotu lub zjawiska, zaobserwowanie go. Jest to więc złożony proces poznawczy, polegający na odzwierciedleniu przez człowieka przedmiotów, zjawisk i procesów (Słownik... 2004). Przetwarzanie informacji odbieranych przez narządy zmysłów odbywa się na dwóch poziomach: sensoryczno-motorycznym i semantyczno-operacyjnym. Na poziomie semantyczno-operacyjnym (znaczeniowo-czynnościowym) nadawane jest przedmiotowi postrzegania określone znaczenie, przypisywane są mu wartości, kształtowane wobec niego są postawy, uczucia i stany emocjonalne. To ten proces jest przedmiotem zainteresowań „geografii percepcji”. 
Badania nad wyobrażeniami przestrzeni miasta zapoczątkował Lynch pracą Image of the city (1960). Uważa on, iż w badaniach percepcji i waloryzacji sprawą ważną jest nie tylko uzyskanie odpowiedzi, jak dana osoba postrzega i ocenia przestrzeń, ale także dlaczego sposób postrzegania i wartościowania jest taki a nie inny. Istotne jest zatem określenie zmiennych wpływających na cały ten proces. Badania wskazują, że o percepcji przestrzeni miejskiej decyduje wiele czynników. Należą do nich: czynniki indywidualne (np. wiek, wykształcenie, wykonywany zawód, stan rodzinny, poziom zamożności, stan emocjonalny, miejsce zamieszkania), czynniki przestrzenne (np. liczba i rodzaj elementów przestrzeni miejskiej, ich zróżnicowanie, funkcjonalność, dostępność komunikacyjna oraz prędkość zmian struktury miasta w czasie), czynniki stanowiące źródło wiedzy o przestrzeni (np. własne doświadczenia, opinie innych osób oraz informacje pochodzące ze środków masowego przekazu) (Libura 1983; Bartnicka 1989; Prawelska-Skrzypek 1990; Jałowiecki, Libura 1992; Madurowicz 2007; Tobiasz-Lis 2013). Każdy więc człowiek oraz każda grupa społeczna będzie posiadała różny obraz przestrzeni miasta.

Współczesne technologie pozwalają na komunikowanie odbioru przestrzeni miejskiej przez osoby mieszkające w tym miejscu, jak i przez odwiedzających. Rozwój internetu i mediów społecznościowych zmienił sposób komunikowania się. Globalna sieć i portale społecznościowe są powszechnie wykorzystywane do poszukiwania i przekazywania przeróżnych informacji. Ważnym elementem społecznej aktywności internautów jest komunikacja nieformalna, która może być skutecznie stosowana w marketingu internetowym. Cechą charakterystyczną nieformalnej komunikacji jest fakt, że wykorzystuje dwa zjawiska: zjawisko sieci (internet) oraz przekaz z ust do ust (Hatalska 2006). Przekaz informacji o przestrzeni miasta, w tym jego walorów turystycznych, może w istotny sposób uzupełniać wiedzę lub kreować potrzeby turystów w zakresie poznawania przestrzeni miast. $Z$ punktu widzenia rozwoju turystyki nieformalna komunikacja może mieć znaczenie w wyborze przez potencjalnych turystów zarówno kierunków, jak i obiektów do zwiedzania. Zamieszczane w przewodnikach i na oficjalnych portalach informacje o cennych zabytkach nie zawsze odpowiadają indywidualnym potrzebom turystów, dlatego poszukują oni w sieci informacji o innych ciekawych obiektach i wydarzeniach. Docierają tym sposobem do źródeł prezentujących subiektywną ocenę przestrzeni miejskiej, nie zawsze odpowiadającą oficjalnemu marketingowi turystycznemu. Wiele miast, szczególnie o dużym potencjale turystycznym, dostrzegło wartość nowych technologii i mediów społecznościowych jako ważnego kanału dystrybucji informacji między zarządzającymi i mieszkańcami oraz turystami. W przestrzeni wirtualnej funkcjonują oficjalne formy przekazu (strony internetowe, portale itp.) oraz mniej oficjalne, tworzone na potrzeby komunikacji ze społeczeństwem, w celu m.in. kreowania przez mieszkańców/turystów wydarzeń oraz obiektów/miejsc wartych odwiedzenia w mieście. W ten sposób miasta dywersyfikują przekaz informacji w różnych mediach 
społecznościowych, biorąc pod uwagę profil ich użytkowników oraz komunikowane treści (Mruk i in. 2012; Brzeziński, Jasiński 2014).

Badanie informacji przekazywanych w świecie wirtualnym o percepcji przestrzeni miast, np. w ramach gier terenowych, stanowi nowe wyzwania dla badaczy geografii percepcji oraz turystyki. Pojawia się tu pole badań nie tylko postrzegania atrakcyjności otoczenia przez graczy, ale także ich wpływu na kreowanie rzeczywistości. Wiedza ta może być wykorzystana do budowania strategii marketingu terytorialnego jako całościowej koncepcji łączącej badanie potrzeb grup docelowych danego miejsca (np. mieszkańców, turystów, inwestorów) oraz zdobytej wiedzy przy podejmowaniu decyzji, orientacji na klienta, wprowadzaniu produktów miejskich odpowiadających oczekiwaniom społeczeństwa, w tym turystów.

Coraz częściej w turystyce wykorzystywane są gry miejskie oparte na geolokalizacji, także jako forma promocji miasta (Mazurkiewicz 2015). Mieszczą się one w szerszym zagadnieniu, jakim jest grywalizacja. Terminem tym określamy zastosowanie elementów gier w sferach niezwiązanych bezpośrednio z nimi (Deterding i in. 2011; Werbach, Hunter 2012). Grywalizacja wykorzystywana jest w turystyce do tworzenia nowych produktów turystycznych i programów ich promocji. Treści turystyczne stosunkowo łatwo dają się fabularyzować poprzez wprowadzenie elementów przygody i wyzwania dla gracza (Kachniewska 2015).

Badania dotyczące Ingressa koncentrują się na roli gry w marketingu terytorialnym, w tym na zwiększeniu atrakcyjności turystycznej miast. Na potencjalne funkcje promocyjne zwraca uwagę Mazurkiewicz (2015), ale większość badaczy, m.in. Weber (2017) i Stark (2016), skupia się na roli Ingressa w postrzeganiu atrakcyjności turystycznej przestrzeni miejskiej. Szczególnie Weber (2017) badała zachowania graczy Ingress, w tym wpływ poziomu zaangażowania grających na postrzeganie przez nich otaczającej przestrzeni.

\section{Metodyka badań}

Przedmiotem zainteresowania autorów były portale gry Ingress, wyrażające postrzeganie atrakcyjności przestrzeni miejskiej małych miast Krakowskiego Obszaru Metropolitalnego (KOM) przez uczestników gry. Problematyka ta mieści się zarówno w zagadnieniach związanych z percepcją przestrzeni miejskiej, jak i grywalizacji w turystyce.

Celem badania była diagnoza percepcji obiektów zabytkowych w małych miastach Krakowskiego Obszaru Metropolitalnego przez graczy gry Ingress. Szczegółowe cele badawcze dotyczyły:

- identyfikacji i klasyfikacji obiektów wprowadzonych przez graczy z przestrzeni miejskiej do rzeczywistości wirtualnej gry Ingress; 
- porównania portali na mapie gry z obiektami zabytkowymi znajdującymi się w rejestrze dziedzictwa kulturowego;

- ustalenia zależności między liczbą zgłoszonych portali do gry Ingress a liczbą mieszkańców miasta (współczynnik korelacji liniowej) oraz przeszłością historyczną miasta;

- ustalenia potencjalnego wpływu gry Ingress na kreowanie produktu turystycznego małych miast KOM;

W postępowaniu badawczym przeprowadzono analizę literatury i materiałów źródłowych oraz wykonano studium terenowe w małych miastach KOM. W pracy posłużono się dokumentacją kartograficzną przestrzeni małych miast zamieszczoną w portalach gry Ingress oraz listą obiektów zabytkowych Ministerstwa Kultury i Dziedzictwa Narodowego. Dokonano inwentaryzacji i klasyfikacji obiektów zgłoszonych przez graczy i zaakceptowanych jako portale występujące na wirtualnej planszy gry Ingress oraz oszacowano pozycję wśród nich obiektów zabytkowych. Lista portali obecnych na planszy gry została zestawiona z urzędowym rejestrem obiektów zabytkowych. Analiza portali umieszczonych w grze Ingress dla wybranych miast pozwoliła określić, jak gracze postrzegają atrakcyjność swojego otoczenia, a tym samym promują miejsca warte odwiedzenia. Obiekty zabytkowe z definicji mają największą wartość historyczną i kulturową, powinny więc być najważniejszymi i najbardziej atrakcyjnymi obiektami, przeniesionymi do rzeczywistości wirtualnej gry. Autorzy są czynnymi graczami gry Ingress, a zdobyte doświadczenia i kontakty pozwoliły na przeprowadzenie ankiety na temat użytkowników gry. W ankiecie wzięło udział 99 respondentów. Wykorzystano także materiały publikowane o graczach Ingress w Polsce (Spis graczy... 2013). Pozyskane w ten sposób dane pozwoliły na formułowanie uogólnień dotyczących wpływu gry Ingress na kreowanie produktu turystycznego.

\section{Obszar badań}

Obszarem badań były małe miasta wchodzące w skład Krakowskiego Obszaru Metropolitalnego (ryc. 1). Obszar metropolitalny jest definiowany jako teren centralnego miasta wraz z sąsiednimi obszarami w granicach powiatów, powiązanymi z nim funkcjonalnie, charakteryzujący się wysokim poziomem jednorodności procesów ekonomicznych i urbanizacyjnych (Trafas, Zborowski 2003; Smętkowski i in. 2009). Krakowski Obszar Metropolitalny zamieszkuje ponad 1,5 mln osób. Obejmuje on Kraków (miasto na prawach powiatu), jako centralną jednostkę osadniczą, oraz 51 gmin. Wchodzą one w skład powiatów: krakowskiego ziemskiego, myślenickiego, wielickiego, bocheńskiego (bez gminy Lipnica Murowana), proszowickiego (bez gminy Radziemice), część gmin powiatu wadowickiego oraz po jednej gminie z powiatów olkuskiego (Trzyciąż) i miechowskiego (Gołcza). 
$\mathrm{Na}$ obszarze KOM zlokalizowanych jest 16 miast, w tym 12 to małe miasta liczące poniżej 20 tys. mieszkańców, które były przedmiotem analizy (ryc. 1). Są to: Dobczyce, Kalwaria Zebrzydowska, Krzeszowice, Myślenice, Niepołomice, Nowy Wiśnicz, Proszowice, Skała, Słomniki, Sułkowice, Świątniki Górne i Wadowice. Wśród wymienionych najstarszymi miastami są Wadowice i Skała, które prawa miejskie uzyskały w XIII w., a później Dobczyce, Proszowice i Słomniki (XIV w.). Kolejne miasta prawa miejskie uzyskały: w XVII w. - Kalwaria Zebrzydowska i Nowy Wiśnicz, Niepołomice w XIX w., natomiast w XX w. - Krzeszowice, Sułkowice i Świątniki Górne. Czas lokacji, pełnione funkcje i sytuacja polityczno-gospodarcza miały istotne znaczenie dla rozwoju urbanistycznego miasta i zachowanych

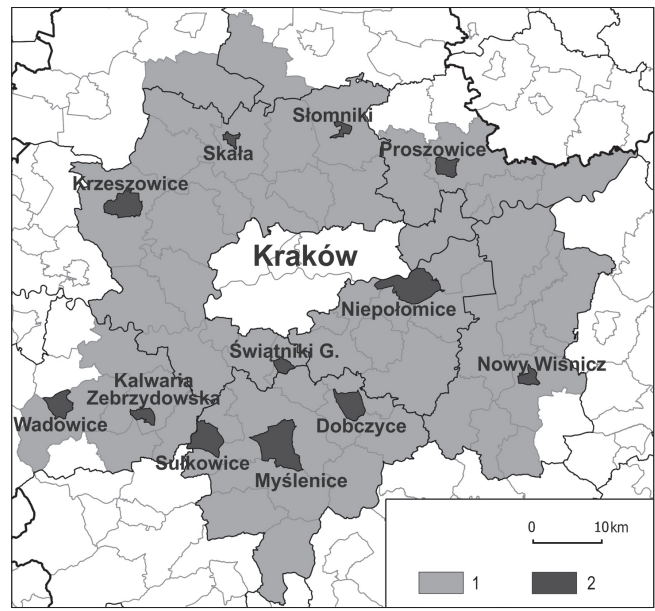

Ryc. 1. Małe miasta w Krakowskim Obszarze Metropolitalnym

Fig. 1. Small towns in the Krakow Metropolitan Area

Objaśnienia: 1 - gminy Krakowskiego Obszaru Metropolitalnego, 2 - małe miasta w Krakowskim Obszarze Metropolitalnym.

Explanations: 1-communes of the Krakow Metropolitan Area, 2 - small towns in the Krakow Metropolitan Area. obiektów dziedzictwa kulturowego. Wymienione miasta są lokalnymi ośrodkami władzy państwowej, a w przeszłości niektóre z nich posiadały przywileje królewskie (Niepołomice, Dobczyce) oraz były siedzibami klasztorów (klasztor Klarysek w Skale do XIV w.). Ośrodkiem kultu religijnego są Kalwaria Zebrzydowska i Wadowice, a typowymi małymi ośrodkami przemysłowymi są Sułkowice i Świątniki Górne. Pod względem geograficznym analizowane miasta położone są w różnych regionach krajobrazowych. Większość z nich zlokalizowana jest w pasie Pogórza Karpackiego (Dobczyce, Myślenice, Kalwaria Zebrzydowska, Wadowice, Sułkowice, Świątniki Górne, Nowy Wiśnicz), na Wyżynie Małopolskiej zaś znajdują się Skała, Krzeszowice i Proszowice, a w Kotlinie Sandomierskiej - Niepołomice.

Ważnym walorem KOM z punktu widzenia rozwoju turystyki jest przede wszystkim nagromadzenie dużej liczby obiektów dziedzictwa kulturowego. Wśród nich są obiekty wpisane na listę światowego dziedzictwa kultury UNESCO: Stare Miasto wraz ze Wzgórzem Wawelskim oraz dzielnicą Kazimierz i Stradom w Krakowie, Kopania Soli w Wieliczce i Bochni, Zamek Żupny w Wieliczce, zespół 
architektoniczno-krajobrazowy i pielgrzymkowy Kalwarii Zebrzydowskiej. Tak duże nagromadzenie obiektów tej klasy stanowi o jego unikatowości i konkurencyjności na rynku turystycznym. Również nagromadzenie obiektów kultury i sztuki występuje w mniejszych ośrodkach, stanowiących składową dziedzictwa kulturowego KOM. Można wśród nich wyróżnić: układy urbanistyczne z różnych okresów, zabytkową zabudowę reprezentującą różne style architektoniczne o charakterze sakralnym, rezydencjonalnym, użyteczności publicznej, obronnej oraz zabytkową zieleń (ogrody, parki).

\section{Obiekty zabytkowe małych miast Krakowskiego Obszaru Metropolitalnego}

Obiekty zabytkowe stanowiące element dziedzictwa kulturowego są ważnym składnikiem atrakcyjności turystycznej miast i rozwoju turystyki oraz najbardziej dostrzegalnym elementem różnicującym ich potencjał turystyczny, szczególnie w dobie postępującej unifikacji i uniformizacji miejskich struktur (Mika 2011). Są one przedmiotem opieki i ochrony ze strony państwa. Ustawa o ochronie zabytków i opiece nad zabytkami szczegółowo reguluje te działania. Według przyjętej ustawy przez zabytek rozumie się: „(...) nieruchomość lub rzecz ruchomą, ich części lub zespoły, będące dziełem człowieka lub związane z jego działalnością i stanowiące świadectwo minionej epoki bądź zdarzenia, których zachowanie leży w interesie społecznym, ze względu na posiadaną wartość historyczną, artystyczną lub naukową" (Ustawa 2003). Zgodnie z przyjętą definicją wiele obiektów dziedzictwa kulturowego wchodzi w zakres terminu „zabytek”. Ustawa wyróżnia kilka typów zabytków. Przedmiotem analizy były zabytki określane w ustawie jako nieruchome. Liczba zlokalizowanych zabytków oraz ich typ zależą od przeszłości historycznej miasta, pełnionych funkcji, zróżnicowania narodowościowego i etnicznego społeczności. Zgodnie z ustawą prowadzona jest ich rejestracja, uzupełniana o nowe obiekty. W wyniku tych działań w świadomości społecznej utrwala się wiedza o tych obiektach, co stanowi przedmiot zainteresowania poznawczego zarówno turystów, jak i lokalnych mieszkańców.

Badania inwentaryzacyjne zmierzające do ustalenia liczby i rodzajów obiektów zabytkowych wpisanych do rejestru zabytków nieruchomych Narodowego Instytutu Dziedzictwa wykazały duże ich zróżnicowanie w analizowanych małych miastach KOM (tab. 1). Największą liczbę obiektów wpisanych do rejestru zabytków posiada wyróżniająca się wybitnymi walorami artystycznymi, przestrzennymi i kompozycyjnymi Kalwaria Zebrzydowska ze znajdującym się na liście UNESCO zespołem klasztornym oo. Bernardynów wraz z założeniem kalwaryjskim obejmującym 44 zabytkowe kaplice i park pielgrzymkowy. Drugim miastem bogatym w obiekty 
zabytkowe są Myślenice z wpisanym do rejestru zespołem urbanistycznym, obiektami sakralnymi, jednostkami użyteczności publicznej i zabytkowymi budynkami mieszkalnymi z XVIII i XIX w. Ośrodkiem miejskim, w którym nie brak zabytkowych obiektów z czasów świetności miasta i uzdrowiska, są Krzeszowice. Układ przestrzenny miasta jest strefą ścisłej ochrony konserwatorskiej, a ochronie podlegają pałace z otaczającymi parkami, zespół zdrojowy, kościół parafialny oraz XIX w. domy. Układ urbanistyczny miasta jest przedmiotem ochrony również w Dobczycach, Wadowicach, Nowym Wiśniczu i Proszowicach. Dobczyce znane są głównie z ruin XIII-wiecznego zamku i pozostałości murów obronnych oraz obiektów sakralnych, w Wadowicach natomiast do rejestru zabytków wpisane są kościoły, cmentarze, zespoły dworskie oraz domy z XIX w. Zespoły zamkowe przyciągające turystów znajdują się w Niepołomicach i Nowym Wiśniczu, w którym szczególnym obiektem jest również zespół klasztorny karmelitów z XVII w. z fortyfikacjami bastionowymi, pełniący obecnie funkcję więzienia.

Podsumowując, należy stwierdzić, że na terenie analizowanych małych miast KOM obiekty sakralne - kościoły i kaplice - stanowią obiekty zabytkowe najczęściej wpisane do rejestru zabytków, a w przypadku trzech miast są to jedyne obiekty w tym rejestrze (tab. 1).

\section{Percepcja obiektów w przestrzeni małych miast KOM zawartych w grze Ingress}

Dokonana inwentaryzacja i kategoryzacja wszystkich wirtualnych portali występujących na planszy gry, a zlokalizowanych w 12 małych ośrodkach miejskich szeroko rozumianego otoczenia Krakowa (tab. 2), pozwoliła na ustalenie pewnych prawidłowości. W przypadku wybranych małych ośrodków miejskich sprawdziła się reguła ogólna, że im większy ośrodek, tym więcej portali (tab. 2). Współczynnik korelacji liniowej między liczbą portali a liczbą mieszkańców wynosi dla badanej próby małych miast 0,68 . Zależność jest więc dość silna. Istnieją jednak odstępstwa od tej reguły. Wadowice mają liczbę ludności zbliżoną do Myślenic (różnica 4\%), ale w tym drugim mieście liczba zgłoszonych portali jest prawie pięć razy mniejsza. Również między Niepołomicami i Krzeszowicami zaobserwowano istotną różnicę. O ile liczba mieszkańców w obydwu miastach jest zbliżona (różnica 9\%), o tyle w Niepołomicach liczba portali umieszczonych na planszy gry jest aż pięciokrotnie większa (tab. 2). Przyczyn tego stanu może być kilka. Może to wynikać z większej liczby potencjalnie atrakcyjnych obiektów na terenie tych ośrodków, jak i z większej liczby samych graczy. Również położenie geograficzne miast, a szczególnie ich dostępność turystyczna i tzw. moda na wybraną aktywność turystyczną, mogą wpływać na zróżnicowaną liczbę graczy i portali. Krzeszowice i Niepołomice znajdują 


\begin{tabular}{|c|c|c|c|c|c|c|c|c|c|c|c|c|}
\hline 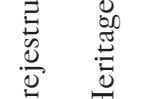 & 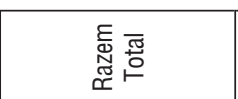 & 10 & i̊ & $\neq$ & $\approx$ & $\sigma \mid \simeq$ & $\underline{v} \nabla$ & $m$ & - & - & - & m \\
\hline$\stackrel{\infty}{\equiv} \quad$ & 离 & ' & ' & - & -7 & - & - & . & ' & . & ' & - \\
\hline 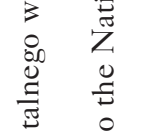 & 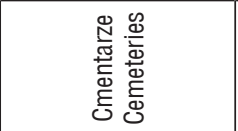 & - & & \begin{tabular}{l|l} 
& \\
\end{tabular} & -1 & -- & -1 & ' & ' & . & ' & m \\
\hline 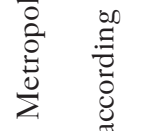 & 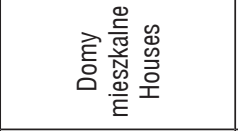 & & ما & $\infty ?$ & 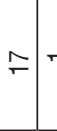 & $-\sim$ & $\begin{array}{lll}v & 1\end{array}$ & - & ' & ' & ' & $\nabla$ \\
\hline 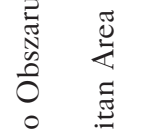 & 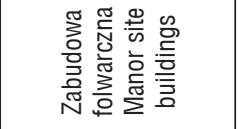 & & ' & $\sim$ & 1 & ' & ' & ' & ' & ' & ' & \\
\hline 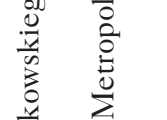 & 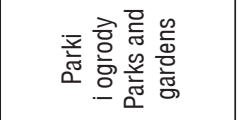 & & $m$ & $\sim c$ & $\sim$ & \begin{tabular}{l|l}
- & 1
\end{tabular} & $\begin{array}{ll}1 \\
1\end{array}$ & ' & ' & . & ' & ' \\
\hline 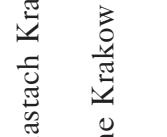 & 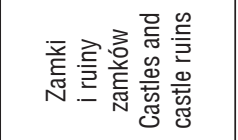 & - & & . & -1 & -- & - & ' & I & ' & ' & \\
\hline 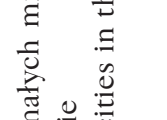 & 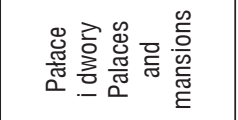 & & $r$ & $\sim c$ & m. & ' & ' & ' & ' & . & ' & - \\
\hline 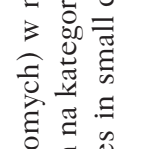 & 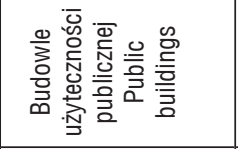 & & & 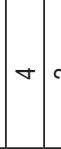 & m & $-m$ & $\begin{array}{ll}0 & 1\end{array}$ & ' & ' & . & ' & - \\
\hline 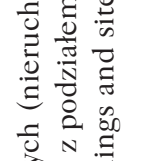 & 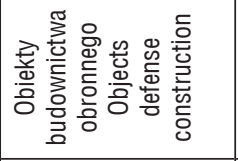 & $-\mid$ & - & ' & \begin{tabular}{l|l}
1 & 1
\end{tabular} & $\cdot \sim$ & $\begin{array}{lll}v & 1\end{array}$ & ' & ' & ' & ' & 1 \\
\hline 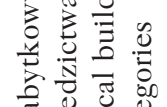 & 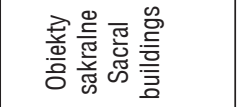 & $\sim$ & o & m & $\nabla m$ & $m$ m & $0 m$ & $\sim$ & - & - & - & ळ \\
\hline 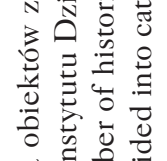 & 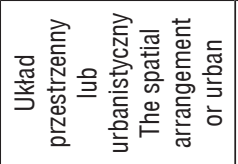 & - & $r$ & - & -1 & $1 \mid-$ & -- & ' & ' & ' & ' & - \\
\hline 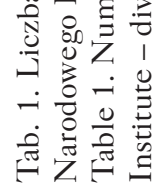 & $\begin{array}{l}\text { 号 } \\
\text { 总 } \\
\text { 竞 }\end{array}$ & 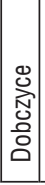 & 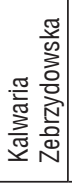 & 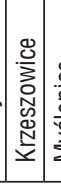 & 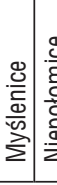 & 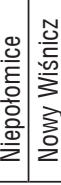 & 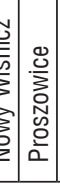 & 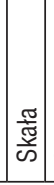 & 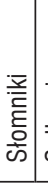 & $\begin{array}{l}3 \\
0 \\
0\end{array}$ & 童 & 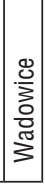 \\
\hline
\end{tabular}

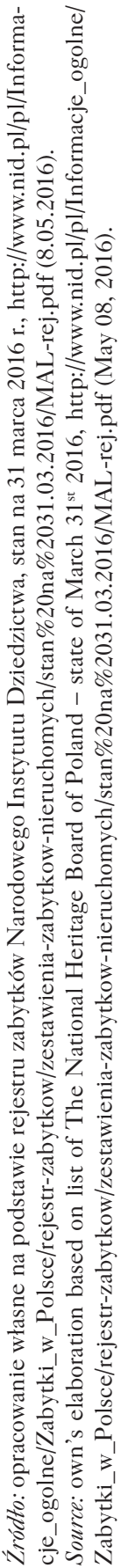


się w bliskim sąsiedztwie Krakowa, są więc potencjalnie atrakcyjnymi miejscami spędzania wolnego czasu (np. sobotnio-niedzielnego) dla mieszkańców aglomeracji krakowskiej. Niepołomice jednak położone są na skraju Puszczy Niepołomickiej, na której obszarze wyznaczono wiele tras pieszych i rowerowych. Może to być istotny czynnik przyciągający turystów, a tym samym aktywnych graczy gry Ingress.

Opierając się na kategoriach zabytków oraz charakterze obiektów najczęściej występujących w grze, podzielono je na 10 grup (tab. 3). Najliczniejszą grupę (1/3 portali) stanowiły obiekty sklasyfikowane jako: na to miały zarówno powszechnie występujące pomniki znanych osobistości, jak i te związane z martyrologią. Niewiele mniejszą liczebnie grupę (ponad 30\%) stanowiły „obiekty sakralne”. W skład tej grupy zaliczono zarówno samodzielne budowle, jak i elementy małej architektury - np. kapliczki. „pomnik, rzeźba, tablica”. Wpływ

Tab. 2. Liczba portali Ingress w małych miastach Krakowskiego Obszaru Metropolitalnego

Table 2. Number of Ingress portals in small towns in the Krakow Metropolitan Area

\begin{tabular}{|l|c|c|}
\hline \multicolumn{1}{|c|}{$\begin{array}{c}\text { Miasto } \\
\text { Town }\end{array}$} & $\begin{array}{c}\text { Liczba portali } \\
\text { Number of portals }\end{array}$ & $\begin{array}{c}\text { Liczba ludności [tys.] } \\
\text { Number of Inhabitants } \\
\text { [in thousand] }\end{array}$ \\
\hline Wadowice & 215 & 19,2 \\
\hline Niepołomice & 124 & 11,2 \\
\hline $\begin{array}{l}\text { Kalwaria } \\
\text { Zebrzydowska }\end{array}$ & 70 & 4,6 \\
\hline Myślenice & 48 & 18,4 \\
\hline Nowy Wiśnicz & 47 & 2,8 \\
\hline Dobczyce & 30 & 6,5 \\
\hline Krzeszowice & 24 & 10,2 \\
\hline Proszowice & 14 & 6,2 \\
\hline Skała & 14 & 3,8 \\
\hline Słomniki & 5 & 4,4 \\
\hline Sułkowice & 5 & 6,5 \\
\hline $\begin{array}{l}\text { Świątniki } \\
\text { Górne }\end{array}$ & 4 & 2,4 \\
\hline
\end{tabular}

Źródto: opracowanie własne na podstawie: https://www. ingress.com/intel (31.05.2016); Bank Danych Lokalnych, https://bdl.stat.gov.pl/ (31.05.2016).

Source: own's elaboration based on: http://ingress.com/ intel (May 31, 2016); Local Database, https://bdl.stat. gov.pl/ (May 31, 2016).

Pozostałe typy portali miały zdecydowanie mniejsze udziały.

Porównanie obiektów-portali małych miast KOM z listą zabytków Narodowego Instytutu Dziedzictwa wykazuje dużą rozbieżność. O ile obiekty sakralne stanowią w grze $1 / 3$ wszystkich portali, o tyle na urzędowej liście jest ich prawie połowa. Różnica ta może wynikać częściowo z charakteru gry, a dobrze to widać na przykładzie cmentarzy. Na liście zabytków najczęściej traktowane są one jako pojedyncze obiekty, które stanowią ok. 7\% wpisanych na listę zabytków, w grze natomiast są to pojedyncze nagrobki czy pomniki. Wśród 600 przeanalizowanych portali obiekty, takie jak cmentarze i nagrobki, stanowią ponad $10 \%$ zbiorowości.

Interesujących informacji dostarczyła szczegółowa analiza wirtualnej przestrzeni dla badanych miast. W miastach o największej liczbie portali umieszczonych w grze, np. w Wadowicach i Niepołomicach, dominują portale typu pomnik, rzeźba 
Tab. 3. Typy portali gry Ingress na terenie małych miast Krakowskiego Obszaru Metropolitalnego Table 3. Types of Ingress portals in small towns in the Krakow Metropolitan Area

\begin{tabular}{|l|c|}
\hline \multicolumn{1}{|c|}{$\begin{array}{c}\text { Rodzaj obiektu } \\
\text { Type of site }\end{array}$} & $\begin{array}{c}\text { Liczba portali } \\
\text { Number of } \\
\text { portals }\end{array}$ \\
\hline $\begin{array}{l}\text { Pomnik, rzeźba, tablica } \\
\text { Monument, figure, plaque }\end{array}$ & 195 \\
\hline Obiekt sakralny / Sacred site & 181 \\
\hline Cmentarz, nagrobek / Cemetery, grave & 62 \\
\hline $\begin{array}{l}\text { Infrastruktura miejska } \\
\text { Urban infrastructure }\end{array}$ & 59 \\
\hline $\begin{array}{l}\text { Zabytek świecki } \\
\text { Non-religious historical site }\end{array}$ & 36 \\
\hline $\begin{array}{l}\text { Obiekt rekreacyjny, sportowy } \\
\text { Recreational or sports facility }\end{array}$ & 28 \\
\hline Mural / Mural & 19 \\
\hline $\begin{array}{l}\text { Instytucja edukacyjna, kulturalna } \\
\text { Ang. Educational or cultural facility }\end{array}$ & 14 \\
\hline Pomnik przyrody / Natural Monument & 4 \\
\hline Mural kibolski / Illegal graffiti & 2 \\
\hline Ogółem / Total & 600 \\
\hline
\end{tabular}

Źródto: opracowanie własne na podstawie: https://www. ingress.com/intel (31.05.2016).

Source: own's elaboration based on: http://ingress.com/ intel (May 31, 2016).

na mapie wirtualnej gry Ingress dla Krzeszowic gracze wprowadzili tylko cztery na 17 obiektów zabytkowych znajdujących się w rejestrze Narodowego Instytutu Dziedzictwa (tab. 1). Na planszy gry umieszczono: kościół parafialny pw. św. Marcina, zespół zdrojowy (częściowo, np. Zdrój Główny), pałacyk Vauxhall i zespół pałacowy. Pozostałe 13 zabytków, w tym kaplica cmentarna, nie zostały uznane przez graczy jako ciekawe obiekty. Do gry zostały natomiast wprowadzone m.in. cztery inne cmentarne obiekty (figury nagrobne) o małych walorach artystycznych. Na mapie gry Ingress umieszczono także rzeźbę „Gladiator”, co wskazywałoby, iż w ocenie graczy jest to obiekt wart poznania. Studium terenowe wykazało, że rzeźba ta jest nowym elementem wprowadzonym do przestrzeni po rewitalizacji centrum Krzeszowic. Równocześnie jest to miejsce spotkań młodzieży, a więc dla tej grupy społecznej odgrywa rolę symboliczną. Interesujący jest fakt, że do gry nie wprowadzono żadnego obiektu przyrodniczego, choć na terenie miasta (parku zdrojowego i miejskiego) występują pomniki przyrody.

lub tablica pamiątkowa (tab. 4, ryc. 2, ryc. 3). Na drugim miejscu znalazły się szeroko pojęte obiekty sakralne. Są tu zarówno kościoły i kaplice, jak i portale reprezentujące mniejsze obiekty - ołtarze, krzyże, przydrożne kapliczki. Duży jest również udział elementów architektury cmentarnej (nagrobki, rzeźby). Obiekty zaś związane z życiem kulturalnym i sportowym miast (biblioteki, domy kultury, place zabaw itp.) stanowiły znikomy udział.

Inny charakter ma struktura portali w Kalwarii Zebrzydowskiej. Obecność rozległego kompleksu pątniczego i klasztornego z jednej strony, a niewielka liczebność ludności miasta z drugiej - wpłynęły na dominację portali reprezentujących obiekty związane z funkcjami religijnymi. Stanowią one ponad połowę portali w tym mieście (tab. 4).

W przypadku pozostałych miast na planszy gry były umieszczane podobne pod względem charakteru obiekty (tab. 4). Na przykład 


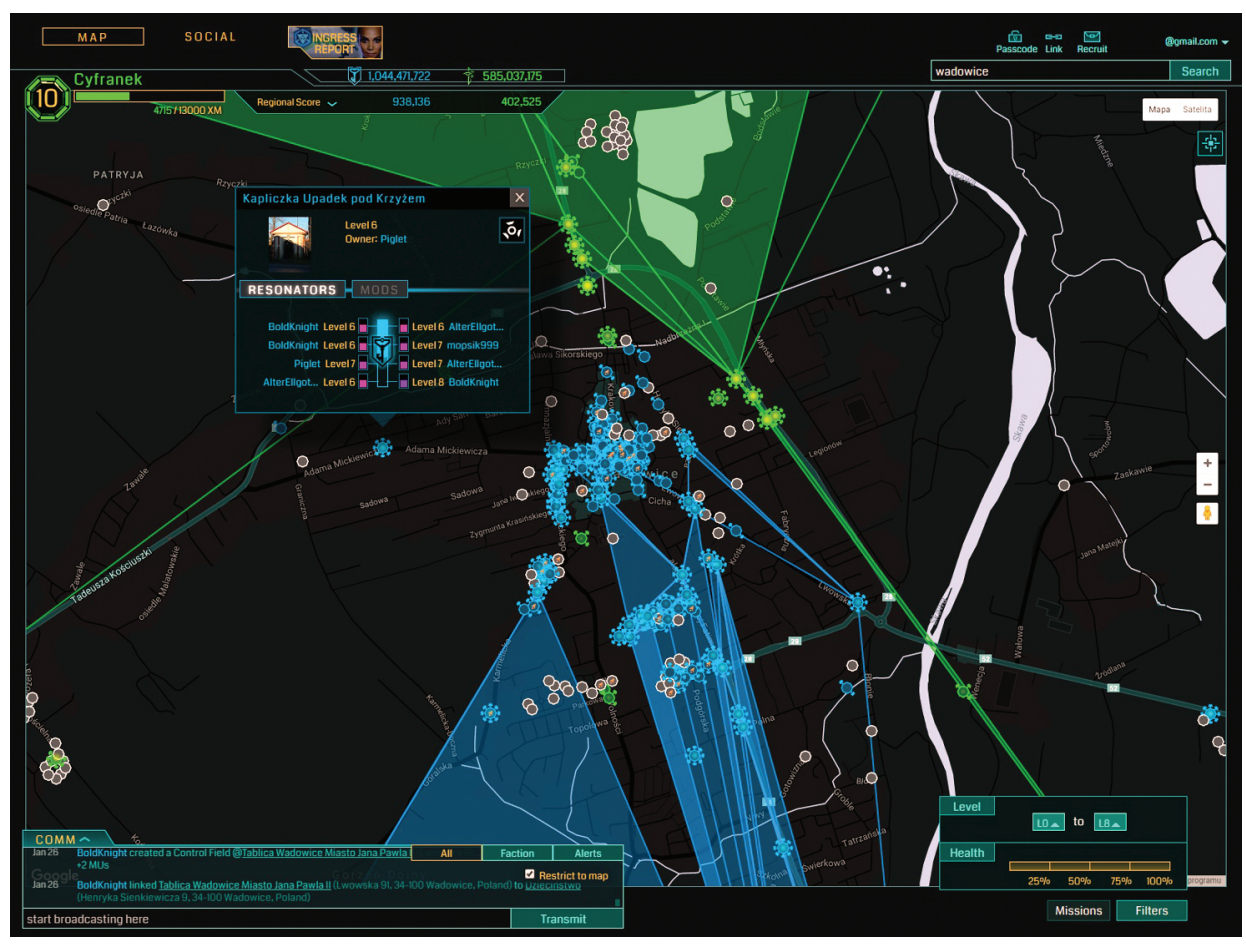

Ryc. 2. Przykład planszy gry Ingress z terenu miasta Wadowice

Fig. 2. Example of Ingress game board from the area of the town of Wadowice Źródto: http://ingress.com/intel (6.07.2016).

Source: http://ingress.com/intel (July 06, 2016). 


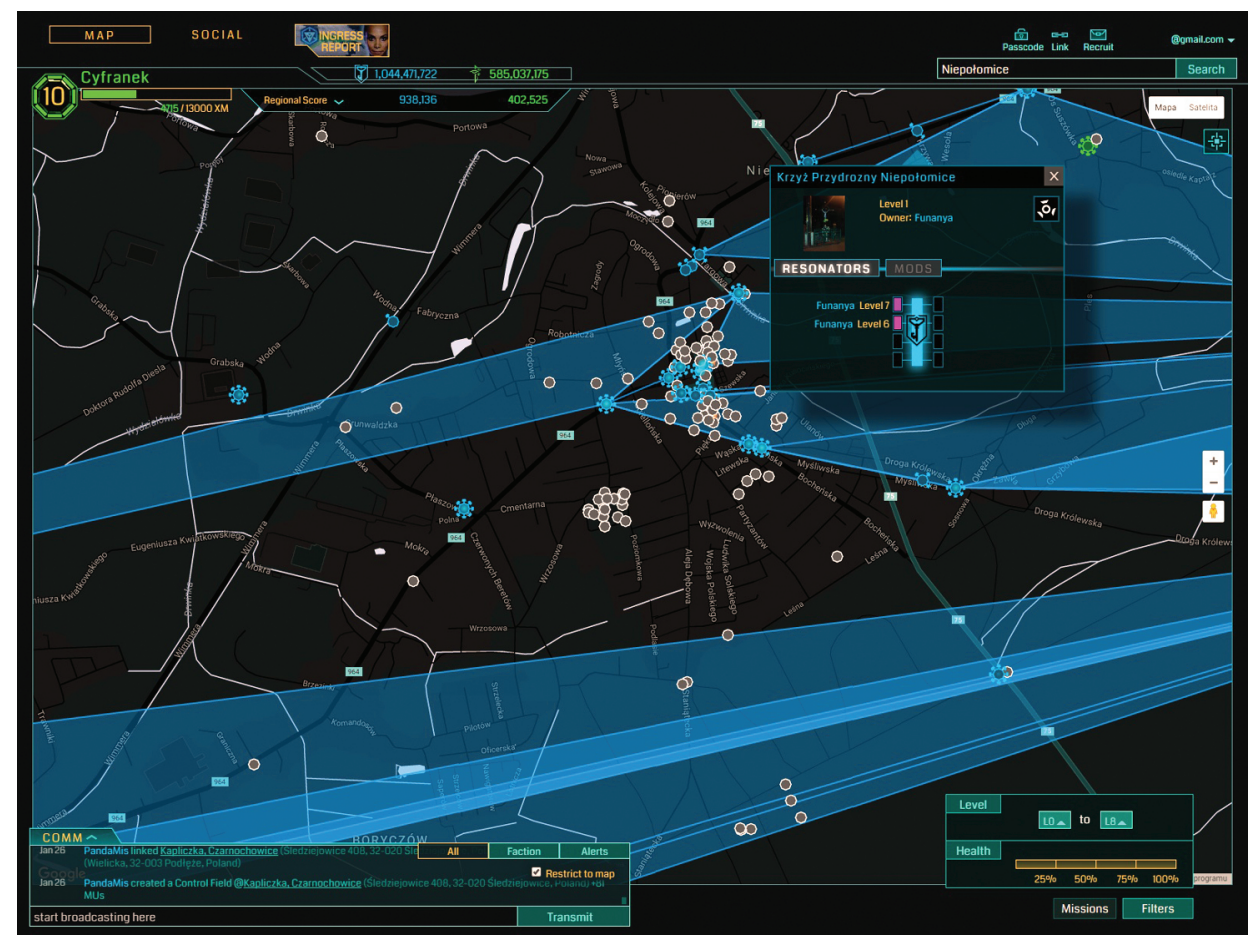

Ryc. 3. Przykład planszy gry Ingress z terenu miasta Niepołomice

Fig. 3. Example of Ingress game board from the area of the town of Niepołomice Źródto: http://ingress.com/intel (6.07.2016).

Source: http://ingress.com/intel (July 06, 2016). 
Tab. 4. Typy portali Ingress w wybranych małych miastach Krakowskiego Obszaru Metropolitalnego (2016 r.)

Table 4. Types of Ingress portals in the same small towns in the Krakow Metropolitan Area (2016)

\begin{tabular}{|c|c|c|c|c|c|c|c|c|c|c|}
\hline \multirow[b]{2}{*}{$\begin{array}{l}\text { Rodzaj obiektu } \\
\text { Type of site }\end{array}$} & \multicolumn{2}{|c|}{$\begin{array}{c}\text { Kalwaria } \\
\text { Zebrzydowska }\end{array}$} & \multicolumn{2}{|c|}{ Niepołomice } & \multicolumn{2}{|c|}{ Wadowice } & \multicolumn{2}{|c|}{ Krzeszowice } & \multicolumn{2}{|c|}{ Skała } \\
\hline & $\begin{array}{l}\text { Liczba } \\
\text { Portali } \\
\text { Number } \\
\text { of portals }\end{array}$ & $\%$ & $\begin{array}{c}\text { Liczba } \\
\text { portali } \\
\text { Number } \\
\text { of portals }\end{array}$ & $\%$ & $\begin{array}{c}\text { Liczba } \\
\text { portali } \\
\text { Number } \\
\text { of portals }\end{array}$ & $\%$ & $\begin{array}{c}\text { Liczba } \\
\text { portali } \\
\text { Number } \\
\text { of portals }\end{array}$ & $\%$ & $\begin{array}{c}\text { Liczba } \\
\text { portali } \\
\text { Number } \\
\text { of portals }\end{array}$ & $\%$ \\
\hline $\begin{array}{l}\text { Pomnik, rzeźba, } \\
\text { tablica } \\
\text { Monument, } \\
\text { figure, plaque }\end{array}$ & 13 & 18,6 & 41 & 33,1 & 82 & 38,1 & 8 & 33,3 & 4 & 50,0 \\
\hline $\begin{array}{l}\text { Obiekt sakralny } \\
\text { Sacred site }\end{array}$ & 41 & 58,8 & 35 & 28,2 & 41 & 19,1 & 6 & 25,0 & 3 & 37,5 \\
\hline $\begin{array}{l}\text { Cmentarz, } \\
\text { nagrobek } \\
\text { Cemetery, grave } \\
\text { site }\end{array}$ & - & - & 15 & 12,1 & 35 & 16,3 & 4 & 16,7 & - & - \\
\hline $\begin{array}{l}\text { Infrastruktura } \\
\text { miejska } \\
\text { Urban } \\
\text { infrastructure }\end{array}$ & 4 & 5,7 & 9 & 7,3 & 26 & 12,1 & 3 & 12,5 & - & - \\
\hline $\begin{array}{l}\text { Zabytek świecki } \\
\text { Non-religious } \\
\text { historical site }\end{array}$ & 1 & 1,4 & 6 & 4,8 & 12 & 5,6 & 2 & 8,3 & 1 & 12,5 \\
\hline Mural / Mural & 3 & 4,3 & 5 & 4,0 & 8 & 3,7 & - & - & - & - \\
\hline $\begin{array}{l}\text { Instytucja } \\
\text { edukacyjna, } \\
\text { kulturalna } \\
\text { Educational or } \\
\text { cultural facility }\end{array}$ & 1 & 1,4 & 3 & 2,4 & 5 & 2,5 & 1 & 4,2 & - & - \\
\hline $\begin{array}{l}\text { Obiekt rekreacyj- } \\
\text { ny, sportowy } \\
\text { Recreational or } \\
\text { sports facility }\end{array}$ & 7 & 10 & 8 & 6,5 & 4 & 1,9 & - & - & - & - \\
\hline $\begin{array}{l}\text { Pomnik przyrody } \\
\text { Natural } \\
\text { monument }\end{array}$ & - & - & 2 & 1,6 & 1 & 0,5 & - & - & - & - \\
\hline $\begin{array}{l}\text { Mural kibolski } \\
\text { Illegal graffiti }\end{array}$ & - & - & - & - & 1 & 0,5 & - & - & - & - \\
\hline
\end{tabular}

Źródto: opracowanie własne na podstawie: https://www.ingress.com/intel (31.05.2016).

Source: own's elaboration based on: http://ingress.com/intel (May 31, 2016). 
W przypadku Skały w przestrzeni wirtualnej gry Ingress na osiem wprowadzonych portali cztery były obiektami zabytkowymi (tab. 1). Trzy obiekty pochodziły z zabytkowego kościoła parafialnego pw. św. Mikołaja (ołtarz JHS, ołtarz bł. Salomei, brama kościelna) i stara dzwonnica. Do gry nie wprowadzono zabytkowego drewnianego domu z XIX w. Pozostałe obiekty wprowadzone do gry mają także charakter sakralny. Są to pomniki Orszak Salomei i św. Floriana oraz krzyż i kapliczka, znajdujące się w centrum miasta (na rynku) i jego sąsiedztwie.

Analiza szczegółowa portali dla małych miast KOM wskazuje, że percepcja obiektów atrakcyjnych w mieście i komunikowanych w przestrzeni wirtualnej przez użytkowników gry Ingress odbiega istotnie od listy zabytkowych obiektów Narodowego Instytutu Dziedzictwa stanowiących o atrakcyjności turystycznej miasta (tab. 1; tab. 2). W dużym stopniu gracze wyeksponowali listę subiektywną obiektów, miejsc godnych zobaczenia i odwiedzenia w badanych miastach. Zawiera ona wprawdzie przykłady obiektów z listy zabytków nieruchomych, ale w większości te, które znajdują się w ścisłym centrum miasta, a także te, przy których umieszczono tablice informacyjne dla turystów.

Przykład portali dla małych miast KOM, umieszczonych w przestrzeni wirtualnej gry Ingress, pokazuje, że rozwój nowych technologii komunikacyjnych sprzyja kreowaniu percepcji przestrzeni miasta przez uczestników gry. Subiektywny wybór miejsc (obiektów), w których byli gracze, a równocześnie poprzez grę polecają je innym zainteresowanym, cały czas rozbudowuje wirtualną sieć informacji. $Z$ badań ankietowych oraz „Spisu graczy w Polsce” (2013) wynika, że w Ingress najczęściej grają ludzie młodzi (20-30 lat), dobrze zaznajomieni z technologiami mobilnymi, uczący się lub studiujący oraz pracujący, często z wyższym wykształceniem, głównie mężczyźni. Znaczna część dziedzictwa kulturowego nie jest jednak przez nich dostrzegana, a przynajmniej nie ma odzwierciedlenia w sferze rozrywki - np. w grze Ingress, co wykazały badania. Do jakiego stopnia fakt ten jest wynikiem zaniedbań edukacji szkolnej i pozaszkolnej o miejscu zamieszkania, a do jakiego wynika z innych pobudek, np. z chęci pokazania nietuzinkowych miejsc (obiektów) lub braku refleksji nad przekazywaną informacją?

Należy także zaznaczyć, że gra Ingress ma charakter dynamiczny. Liczebność, jak i udział portali z wyróżnionych grup, będzie się zmieniać, gdyż przejmowanie portali wiąże się z wprowadzaniem nowych obiektów do gry. Potencjalnie może to wzbudzać zainteresowanie i ciekawość grających, a tym samym kreować nowe obiekty do zwiedzania w mieście. Z obserwacji autorów wynika, że początkujący gracze skupiają się głównie na zdobywaniu największej liczby portali, natomiast mało uwagi poświęcają dokonywaniu selekcji obiektów wprowadzanych do gry (ich wartości kulturowe, edukacyjne itp.). Może to mieć wpływ na kreowanie małowartościowego produktu turystycznego miast. Zaawansowani gracze większą uwagę zwracają na poznawanie otoczenia, a nie tylko „zaliczanie” portali. Wprowadzają do gry obiekty o większych 
walorach poznawczych, często poza przewodnikowe atrakcje, tym samym usuwają z przestrzeni wirtualnej atrakcje o wątpliwej wartości. Podobne zachowania graczy Ingress odnotowują inni badacze (Weber 2017). Zaawansowani gracze mogą mieć zatem realny wpływ na kreowanie atrakcyjności turystycznej lokalnego otoczenia, a poprzez rozwiązania technologiczne zachęcać uczestników gry do ich odwiedzenia.

\section{Wnioski}

Technologie mobilne stają się istotnym elementem codziennej aktywności. Wchodzą również w zakres sposobów spędzania czasu wolnego, już nie tylko w postaci gier. Gra Ingress łączy z sobą atrakcyjność gry elektronicznej i możliwość odwiedzania atrakcyjnych obiektów i miejsc. Wśród największych zalet gry wymienia się jej globalny zasięg, gdyż można w nią grać zarówno w małym miasteczku, jak i w metropolii. Druga ważna zaleta jest taka, że zmusza osoby do wyjścia w teren i odwiedzenia miejsc, które inni gracze uznali za atrakcyjne. Grający w Ingress samodzielnie kształtują planszę gry, opierając się na realnych obiektach znajdujących się w terenie. Sami je wyszukują i nadają im rangę poznawczą w grze.

Wyniki przeprowadzonego studium na przykładzie małych miast KOM pozwoliły na ustalenie trzech istotnych faktów. Po pierwsze, wirtualny świat atrakcyjnych obiektów wprowadzonych przez graczy do gry znacznie odbiega od obrazu kształtowanego przez przewodniki turystyczne i historyczną przeszłość miast. Liczba portali w grze Ingress dla danego miasta nie odzwierciedla liczby i charakteru zabytków znajdujących się w rejestrze dziedzictwa kulturowego. Po drugie, zaobserwowano silną zależność liczby portali wprowadzonych do gry Ingress od liczby mieszkańców miejscowości (tab. 2). Po trzecie, liczba portali w grze Ingress dla danego miasta zależy nie tylko od przeszłości historycznej i pełnionych funkcji (np. Kalwaria Zebrzydowska, Myślenice), lecz także jest modyfikowana przez bieżące wydarzenia, znane osoby, jak to się dzieje w przypadku Wadowic, oraz poziom zaawansowania grających. Ponadto liczba portali zależy od detali architektonicznych i małej architektury miasta (tab. 3). Bardzo często jako portale pojedynczych obiektów na liście zabytków odzwierciedla w grze wiele portali (np. poszczególne tablice wmurowane w ściany zewnętrzne i wewnętrzne, elementy architektoniczne - dzwonnica, witraż, portal, brama).

Szczegółowa analiza i inwentaryzacja portali w małych miastach KOM wykazała, że charakter portali jest dość podobny. Pomiędzy poszczególnymi ośrodkami występują jednak różnice, w zależności od specyfiki ośrodków miejskich. Najbardziej charakterystyczne elementy przestrzeni analizowanych miast w grze Ingress to:

- dominacja tablic pamiątkowych, rzeźb, pomników - elementów małej architektury (195); 
- dominacja obiektów związanych z kultem religijnym - kościoły, kapliczki, figury świętych (181);

- znikoma liczba obiektów rekreacyjnych, edukacyjno-kulturalnych (tab. 2).

Wśród polskich graczy znajomość obiektów o realnej wartości zabytkowej wydaje się niewielka. Dominuje postrzeganie własnego miejsca zamieszkania poprzez miejsca kultu religijnego i związanych z nim obiektów (figury, kapliczki) oraz obiekty małej architektury (tablice pamiątkowe, pomniki). Widoczny jest brak działań miast w kreowaniu mapy gry poprzez wprowadzanie portali, które pokazywałyby obiekty zabytkowe warte zobaczenia oraz inne obiekty warte wypromowania. Wykorzystanie nowoczesnej strategii marketingu terytorialnego, opartego na portalach społecznościowych i grach miejskich, jest mało popularne w małych miastach KOM. Władze samorządowe nie dostrzegają jeszcze możliwości wykorzystania tego sposobu promowania miasta - poprzez włączenie istotnych dla jego życia obiektów do bazy najpopularniejszej platformy mobilnych gier terenowych - Ingress i Pokémon GO. Również nie dokonują dywersyfikacji przekazu informacji o mieście, w tym o oferowanych atrakcjach w odniesieniu do grup turystycznych. W świetle literatury wynika, że to dzięki działaniom podejmowanym w ramach marketingu miasta internauci mogą stać się prawdziwymi ambasadorami miejsca (tzw. zjawisko $e$-word-of-mouth, elektroniczny marketing szeptany) (Schell 2008; Koplan, Haenlem 2010; Szromnik 2016). Popularność nowych portali, np. Foursquare (dedykowany zjawisku meldowania się i komentowania odwiedzanych miejsc), Instagram (poświęcony tworzeniu i dzieleniu się zdjęciami wykonanymi przez telefon komórkowy), powinna być bardziej wykorzystana przez osoby zajmujące się promowaniem turystyki w małych miastach, w tym do tworzenia interaktywnych gier miejskich i specjalnych akcji marketingowych. Jest to jeden ze sposobów docierania z produktem turystycznym do różnych grup odbiorców.

Problematyka percepcji atrakcyjności turystycznej otoczenia wymaga dalszych, pogłębionych badań. Przedstawione wyniki nie pozwalają jeszcze na wyciąganie daleko idących wniosków dotyczących realnego wpływu gry Ingress na zwiększenie ruchu turystycznego. Zgodnie z zasadą gry ma ona zachęcać do wyjścia w teren i poznawania atrakcyjnych obiektów, nie tylko w najbliższym otoczeniu, ale także poza miejscem zamieszkania. Ten element gry jest istotnym walorem promocji produktu turystycznego. Przeprowadzone badania wskazują jednak, że obiekty zabytkowe z listy Narodowego Instytutu Dziedzictwa nie znajdują w pełni odzwierciedlenia w wirtualnym świecie gry Ingress, kształtowanej przez młode osoby. Pozostaje zatem pytanie otwarte - z czego wynika rozdźwięk pomiędzy wiedzą, świadomością i odbiorem otoczenia przez młodych ludzi? 


\section{Literatura}

Bajgier-Kowalska M., Tracz M., Uliszak R., 2017, Obiekty zabytkowe w przestrzeni wirtualnej gry Ingress na przyktadzie miasta Krzeszowice, [w:] I. Kapera, M. Bajgier-Kowalska (red.), Turystyka i rekreacja. Wspótczesne zagrożenia oraz możliwości rozwoju, Oficyna Wydawnicza AFM, Kraków, 69-83.

Bank Danych Lokalnych, GUS, Warszawa, https://bdl.stat.gov.pl/ (31.05.2016).

Bartnicka M., 1989, Wyobrażenia præestræeni miejskiej Warszawy (studium geografii percepcji), Dokumentacja Geograficzna, 2, Instytut Geografii i Przestrzennego Zagospodarowania PAN, Warszawa.

Bierwiaczonek K., 2008, Percepcja $i$ waloryzacja præestræeni miasta. Studium porównawcæe z socjologii przestrzeni na przyktadzie Będzina, Cieszyna, Mikotowa i Żywca, Wydawnictwo Górnośląskiej WSP, Mysłowice.

Brzeziński S., Jasiński M., 2014, Media spotecznościowew marketingu terytorialnym polskich miast, Marketing i Rynek, 3, 9-17.

Deterding S., Dixon D., Khaled R., Nacke, L., 2011, From game design elements to gamefulness: Defining "Gamification”. Proceedings from MindTrek '11. ACM, Tampere, Finland, https://www.cs.auckland.ac.nz/courses/compsci747s2c/lectures/paul/definitiondeterding. pdf (10.06.2016).

Gold J.R., 1980, An introduction to Behavioural Geography, Oxford University Press, Oxford.

Guelke L., 1976, Interdyscyplinary research and environmental perception, Proceedings, Association of American Geographers, 5, 184-188.

Hatalska N., 2006, Marketing szeptany. Mechanizmy działania niestandardowych form komunikacji marketingowej, [w:] M. Kokocińska (red.), Funkcjonowanie wspótczesnych gospodarek i przedsiębiorstw. Aspekty globalne, regionalne, sektorowe, Wydawnictwo Akademii Ekonomicznej w Poznaniu, Poznań, http://www.hatalska.com/wp-content/uploads/2009/02/N. Hatalska_MarketingSzeptany_FunkcjonowanieWspolczesnychGospodarekIPrzedsiebio rstw2006.pdf (10.05.2016).

Ingress - Pomoc, https://support.ingress.com/hc/pl (31.05.2016).

Jałowiecki B., Libura H. (red.), 1992, Percepcja i waloryzacja środowiska naturalnego i antropogenicznego, Wydawnictwa Uniwersytetu Warszawskiego, Warszawa.

Kachniewska M., 2015, Potencjat mediów spotecznościowych w obszarze popularyzacji aktywności turystycznej, Rozprawy Naukowe Akademii Wychowania Fizycznego we Wrocławiu, 50, $35-48$.

Koplan A.M., Haenlem M., 2010, User of the world unite! The challenges and opportunities of Social Media, Business Horizons, 53, 59-68.

Kowalczyk A., 2003, Geografia turyzmu, Prace i Studia Geograficzne, 32, Warszawa.

Kowalczyk A., 2008, Wspótczesna turystyka kulturowa - między tradycjq a nowoczesnościq, [w:] A. Kowalczyk (red.), Turystyka kulturowa. Spojrzenie geograficzne, Wydział Geografii i Studiów Regionalnych UW, Warszawa, 9-58. 
Libura H., 1983, Niektóre aspekty kartograficzne map wyobrażeniowych, Polski Przegląd Kartograficzny, 15 (3), 126-132.

Libura H., 1990, Percepcja præestrzeni miejskiej, Uniwersytet Warszawski, Instytut Gospodarki Przestrzennej, Warszawa.

Lisowski A., 2003, Koncepcje przestrzeni w geografii cztowieka, Wydział Geografii i Studiów Regionalnych UW, Warszawa.

Lynch K., 1960, The image of the city, Harvard University Press, Cambridge.

Madurowicz M. (red.), 2007, Percepcja wspótczesnej przestrzeni miejskiej, Wydział Geografii i Studiów Regionalnych UW, Warszawa.

Mazurkiewicz B., 2015, Gry miejskie oparte na lokalizacji jako sposób promocji miasta, Handel Wewnętrzny, 4 (357), 328-336.

Metelka Ch.J., 1990, The dictionary of hospitality, travel and tourism, Delmar Publishers Ins., Merton House Travel and Tourism Publishers, Albany NY.

Mika M., 2007, Turystyka miejska, [w:] W. Kurek (red.), Turystyka, Wydawnictwo Naukowe PWN, Warszawa.

Mika M., 2011, Miasta jako obszary recepcji turystycznej, [w:] M. Mika (red.), Kraków jako ośrodek turystyczny, Uniwersytet Jagielloński, Instytut Geografii i Gospodarki Przestrzennej, Kraków, 15-34.

Mikos von Rohrscheidt A., 2008, Turystyka kulturowa. Fenomen, potencjat, perspektywy, Wydawnictwo KMB Druk, Gnieźnieńska Wyższa Szkoła Humanistyczno-Menedżerska Milenium, Gniezno.

Mruk H., Pilarczyk B., Sławińska M., 2012, Marketing. Koncepcje - strategie - trendy, Wydawnictwo Uniwersytetu Ekonomicznego w Poznaniu, Poznań.

Prawelska-Skrzypek G., 1990, Miasta o niezharmonizowanym rozwoju w świadomości mieszkańców (na przykładzie miast polskich), nakł. Uniwersytetu Jagiellońskiego, Kraków.

Relph E.C., 1970, The phenomenological foundations of geography, University of Toronto, Toronto.

Saarinen T.F., 1973, Students' view of the world, [w:] R.M. Downs, D. Stea (red.), Image and environment: Cognitive mapping and spatial behavior, Edward Arnold, Chicago.

Sagan I., 2000, Miasto - scena konfliktów i wspótpracy, Wydawnictwo Uniwersytetu Gdańskiego, Gdańsk.

Schell J., 2008, The art of game design: A book of lenses, Morgan Kaufmann Publishers, Burlington, USA.

Stownik jezyka polskiego, 2004, Wydawnictwo Naukowe PWN, Warszawa.

Smętkowski M., Jałowiecki B., Gorzelak G., 2009, Obsæary metropolitalne w Polsce - diagnoza i rekomendacje, Studia Regionalne i Lokalne, 1 (35), 52-73.

Spis graczy Ingress w Polsce, 2013, https://infogr.am/Spis-graczy-Ingress-w-Polsce (31.05.2016). Stark E., 2016, Playful places: Uncovering hidden heritage with Ingress, [w:] M. Willson, T. Leaver (red.), Social, Casual and Mobile Games: The Changing Gaming Landscape, Bloomsbury Publishing, 149-164.

Szromnik A., 2016, Marketing terytorialny. Miasto i region na rynku, wyd. V poszerz., Wolters 
Kluwer Polska SA, Kraków.

Tobiasz-Lis P., 2013, Zmiany wyobrażeń mieszkańców Łodzi o przestrzeni miasta, Wydawnictwo Uniwersytetu Łódzkiego, Łódź.

Trafas K., Zborowski A., 2003, Metropolia Krakowa-Krakowski Obsæar Metropolitalny (materiaty do Planu Zagospodarowania Præestrzennego Woj. Małopolskiego), Urząd Marszałkowski Woj. Małopolskiego, Kraków.

Trowbridge C.C., 1913, On fundamental methods of orientation and imaginary maps, Science, 38, 888-897.

Ustawa, 2003, Ustawa z dnia 23 lipca 2003 r. o ochronie zabytków i opiece nad zabytkami, Dz.U. 2003 nr 162 poz. 1568.

Warcholik W., Leja K., 2012, Gry miejskie jako innowacyjne produkty turystyczne, Annales Universitatis Paedagogicae Cracoviensis Studia Geographica, 3, 87-97.

Weber J., 2017, Designing engaging experiences with location-based augmented reality games for urban tourism environments, Doctorate Thesis (Doctorate), Bournemouth University, http://eprints. bournemouth.ac.uk/27176/ (5.05.2017).

Werbach K., Hunter D., 2012, For the Win: How game thinking can revolutionize your business, Wharton Digital Press, Philadelphia.

Wright J.K., 1947, Terrae incognitae: The place of the imagination in geography, Annals of the American Association of Geographers, 37, 1-15.

Yi-Fu Tuan, 1987, Przestrzeń i miejsce, PIW, Warszawa.

Matgor:ata Bajgier-Kowalska

Krakowska Akademia im. Andræeja Frycza Modrzewskiego

Wydziat Prawa, Administracji i Stosunków Międzynarodowych

ul. Gustawa Herlinga-Grudzińskiego 1, 30-705 Kraków

malbajkow@interia.pl

Mariola Tracs

Kolegium Europejskie, Centrum Edukacji Międzynarodowej w Krakowie

ul. Metalowców 6, 31-084 Kraków

mtracz-62@o2.pl

Radostaw Ulis\&ak

VIII Prywatne Akademickie Liceum Ogólnoksstatcace w Krakowie

ul. Karmelicka 45, 31-128 Kraków

sgulisza@cyf-kr.edu.pl 
